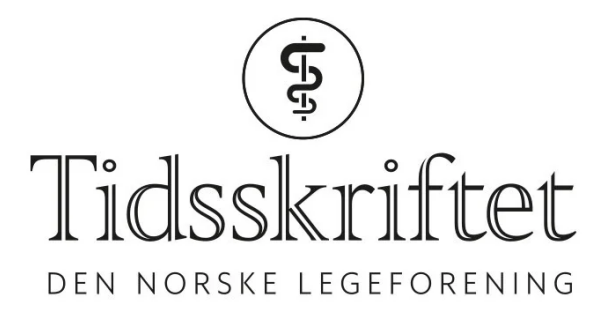

\title{
Burde leger behandle andre leger gratis?
}

TIDLIGERE I TIDSSKRIFTET

\section{JULIE DIDRIKSEN}

julie.didriksen@tidsskriftet.no

Tidsskriftet

I utgave 12/1918 dukket det opp en notis om en rettssak som hadde funnet sted i Preussen. En lege hadde nemlig hatt en annen lege som pasient, med 20 besøk og minst 300 konsultasjoner. Men da tiden var inne for å sende regningen, ville ikke pasienten betale. For var det ikke vanlig praksis at kolleger behandlet hverandre gratis? (Tidsskr Nor Lægeforen 1918; 35:544-5)

Honorar for behandling av kolleger.

Spørsmaalet om, hvorvidt en læge kan ta sig betalt for at ha behandlet en kollega, har nylig været indbragt for domstolene i Preussen.

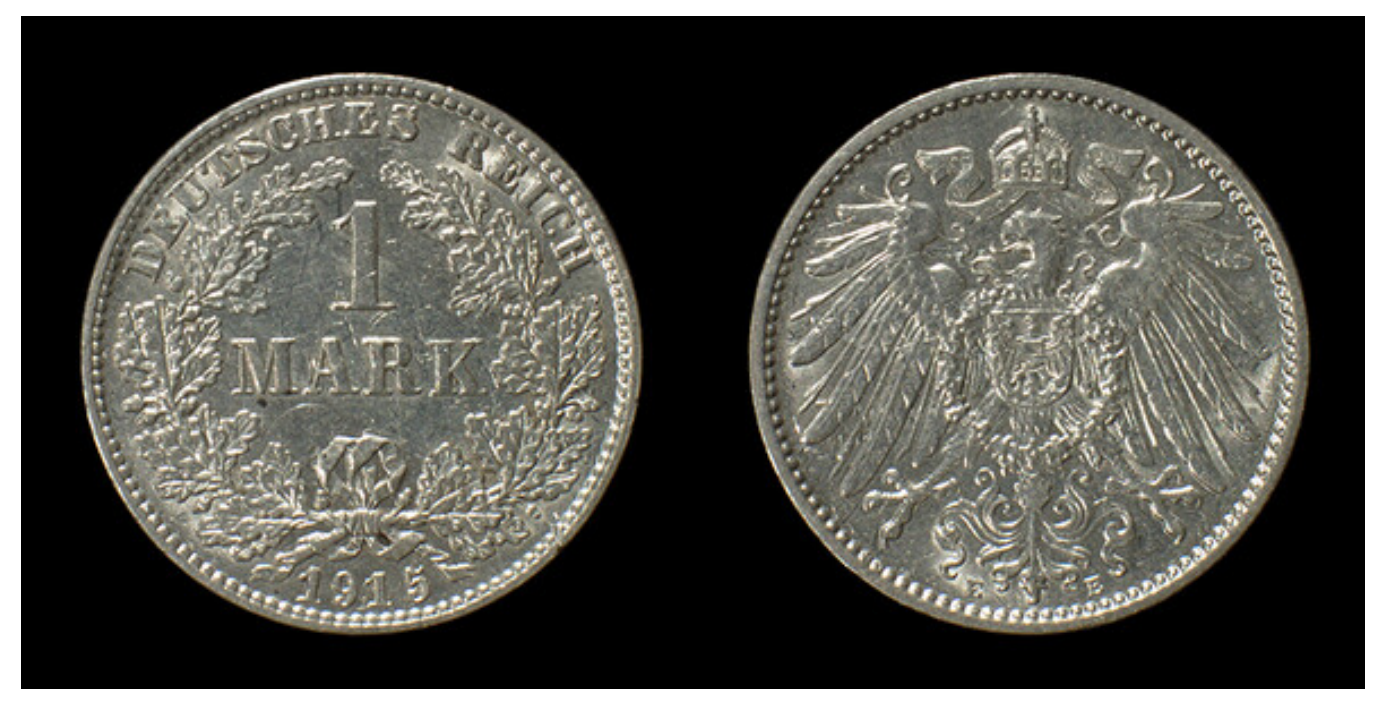


Illustrasjon: Johannes Robalotoff/CC BY-SA 3.o DE

Saken gjaldt behandling av en irit, som førte til næsten komplet sammenvoksning av pupillen, og derfor hadde krævet meget nøiagtig undersøkelse og kontrol. Der blev utført 20 besø $\mathrm{k}$ og mindst 300 konsultationer. Efter preussisk takst beregnet vedkommende læge sig: 20 bes $\varnothing \mathrm{k}$ à $10 \mathrm{M} .=200 \mathrm{M}$., 300 konsultationer à 5 M. $=1500$ M., tils. 1700 M. Patienten bestred det paastaaede omfang av behandlingen og likesaa berettigelsen av honorarets størrelse, da det her dreiet sig om ganske enkle astropininddrypninger; dertil kom som det væsentlige, at det var aldeles uberettiget at kræve honorar, fordi det er almindelig sedvane blant læger, at man intet tar for gjensidig behandling.

\section{«Alle laeger, deres hustruer og hjemmevcerende barn bør nyde frit tilsyn og behandling av de laeger, hvis hjcelp de maatte ønske; de bør erholde fri konsultation eller kortere tids behandling hos specialister»}

Retten (Oberlandsgericht) indhentet uttalelse fra vedkommende lægekammer om:1) det var hævdvunden sedvane, at kolleger behandler hverandre gratis, 2) om dette ogsaa gjælder for specialister og for langvarigere behandling. Efter at ha faat svar paa disse spørsmaal fandt retten at maatte avvise saken, fordi det fra lang tid tilbake var skik og bruk, at læger av kollegiale hensyn behandlet hverandre uten nogen betaling, og det selv om det gjælder en specialists langvarige behandling. Visstnok hadde lægekamret nævnt, at der oftere hadde hævet sig stemmer i tidsskrifterne mot denne skik, og i enkelte tilfælder var der betalt honorar for længere tids behandling; men det fremgik jo herav, at denne sedvane i almindelighet endnu bestaar, om man end bestræber sig for efter hvert at faa den ophævet.

[Hos os har man som bekjendt § 10 i «Kollegiale bestemmelser», som siger: «Alle læger, deres hustruer og hjemmeværende barn bør nyde frit tilsyn og behandling av de læger, hvis hjælp de maatte ønske; de bør erholde fri konsultation eller kortere tids behandling hos specialister $\rightarrow$ osv.]

(Münch. med. Wochenschrift 1918, nr.19).

I. Kobro.

Publisert: 25. oktober 2021. Tidsskr Nor Legeforen. DOI: 10.4045/tidsskr.21.0459

(C) Tidsskrift for Den norske legeforening 2023. Lastet ned fra tidsskriftet.no 26. april 2023. 